\title{
Effect of Two Therapies and Gender on Reading Skills of Pupils with Learning Disabilities
}

\author{
Udeme Samuel Jacob ${ }^{1,2, *}$, Kelechi Uchemadu Lazarus², Jace Pillay ${ }^{3}$, Hammed Gbenga Adewale ${ }^{2}$ \\ ${ }^{1}$ Postdoctoral Research Fellow, South African Research Chair in Education and Care in Childhood, Faculty of Education, \\ University of Johannesburg, South Africa. \\ ORCID: 0000-0002-3234-8226 \\ ${ }^{2}$ Department of Special Education, University of Ibadan, Oyo state, Nigeria \\ ORCID: 0000-0001-8347-3206 \\ ${ }^{3}$ South African Research Chair in Education and Care in Childhood, Faculty of Education, University of Johannesburg, South Africa \\ ORCID: 0000-0002-9432-6014
}

Received September 16, 2021; Revised October 26, 2021; Accepted November 21, 2021

\section{Cite This Paper in the following Citation Styles}

(a): [1] Udeme Samuel Jacob, Kelechi Uchemadu Lazarus, Jace Pillay, Hammed Gbenga Adewale, "Effect of Two Therapies and Gender on Reading Skills of Pupils with Learning Disabilities," Universal Journal of Educational Research, Vol. 10, No. 1, pp. 48 - 56, 2022. DOI: 10.13189/ujer.2022.100105.

(b): Udeme Samuel Jacob, Kelechi Uchemadu Lazarus, Jace Pillay, Hammed Gbenga Adewale (2022). Effect of Two Therapies and Gender on Reading Skills of Pupils with Learning Disabilities. Universal Journal of Educational Research, 10(1), 48 - 56. DOI: 10.13189/ujer.2022.100105.

Copyright $\bigcirc 2022$ by authors, all rights reserved. Authors agree that this article remains permanently open access under the terms of the Creative Commons Attribution License 4.0 International License

\begin{abstract}
Reading is a fundamental skill required for effective participation in academic tasks. This research investigated the significant main effects of phonics and neurological impress instructional methods on the reading skills of pupils with learning disabilities. A quasi-experimental pretest-posttest control group design with a $3 \times 2$ factorial matrix was used. Purposive sampling was used to select forty-five students with learning disabilities $(\mathrm{N}=45, \mathrm{M}=22, \mathrm{~F}=23$, Mean age $=9.3)$ from three government-owned primary schools. Six instruments were used: Pupil Rating Scale (Revised) $(r=0.75)$; Picture Vocabulary Test $(r=0.75)$; PALS-PreK $(r=0.82)$; Informal Reading Inventory $(r=0.70)$; and Umolu' s One Hundred High Frequency Words $(r=0.85)$. The data collected were analysed using the analysis of covariance (ANCOVA) and an estimated marginal mean score of 0.05 level is of significance. The findings revealed that treatment had a significant main effect on the reading skills of students with learning disabilities $\left(\mathrm{F}_{(2,42)}=43.178, p\right.$ $<.05, \eta^{2}=.762$ ), but gender had no significant main effect. It is recommended that phonics and neurological impress instructional methods be adopted when teaching reading skills to pupils with learning disabilities.
\end{abstract}

Keywords Phonics, Neurological Impress Method, Reading Skills, Pupils with Learning Disabilities

\section{Introduction}

Poor readers waste time attempting to identify words and generally read the text verbatim. They are unable to develop a conceptual understanding of what is reading because they spend so much time on identifying individual words in the text. Research shows that pupils who are unable to read by the fourth grade are more likely to drop out of school before graduating $[1,2]$, which will affects a large percentage of school-age children. The Individuals with Disabilities Education Act 2004 (USA) noted that approximately 2.9 million school-age children have specific learning disabilities and receive special education. In fact, $80 \%$ of the pupils with learning disabilities struggle to learn to read and half of the population struggles to read, while dyslexia affects $2 \%$ to $8 \%$ of the school-age children $[3,4]$. In most developing countries, including Nigeria, these figures are unknown.

Reading difficulties lead to poor academic skills because those who suffer from them are unable to comprehend printed or written messages; however, pupils with reading difficulties are likely to perceive reading exercises as punishments. Fluent readers, on the other 
hand, can easily identify words and thus have better comprehension of what they read. The development of effective reading skills is required for the social and intellectual development and growth of man $[5,6]$. It also serves as a good resource for an individual to succeed in life [7]. Pupils with poor reading skills face challenges in different academic subjects [8]. Reading difficulties exhibited by pupils with learning disabilities are due to various reasons, such as limited vocabulary, poor auditory and visual perception, limited spoken language ability, listening problems, and poor instructional strategies [9]. Researchers and professionals frequently underestimate the importance of developing efficient reading skills among pupils with learning disabilities. As a result, previous reading instruction strategies for these students were ineffective and severely limited to sight words $[10$, $11,12]$.

Therefore, questions regarding the best instructional method for teaching reading to pupils with learning disabilities remain unanswered. Can phonics and neurological impress instructional methods be considered evidence-based practices for improving the reading skills of pupils with learning disabilities? Which instructional components or conditions of implementation will improve the efficacy of the two strategies for pupils with learning disabilities? These data will enable stakeholders to develop and implement effective reading interventions for these pupils. As a result, the goal of this research was to examine the efficacy of phonics and neurological impress methods in improving reading skills of students with learning disabilities.

\section{Literature Review}

\section{Facts about learning disabilities}

In Nigeria, there are no research data on the prevalence of learning disabilities among pupils in the country but reading difficulty is a condition prevalent in Nigeria. Most pupils experience one or more difficulties with reading in classrooms without being formally diagnosed. According to Fletcher [13] and the National Reading Panel [14], reading difficulty is common among pupils with learning disabilities, and it frequently coexists with ineffective cognitive processing and poor attention span. Without a doubt, teaching students to read is a critical and distinct function assigned to schools as a whole and, as such, schooling and literacy are two sides of a coin. As a result, when a school fails to meet its responsibility of ensuring that students develop efficient and effective reading skills, it is viewed as an aberration, and the view is that the expertise of a special educator is required to correct the problem [15].

According to Schuchardt, Hasselhorn, and Mähler [16], pupils with learning disabilities struggle with working memory and central executive functioning due to significant limitations in acquiring the core skills required for effective reading. It is important to note that learning disabilities can lead to ineffective cognitive processing in areas such as organisation, time management, abstract thinking, short- and long-term memory, attention span, and pupils' overall academic skills [17]. Differences in how the brain processes written words and text are commonly the cause of reading disabilities $[18,19]$. Pupils with learning disabilities have difficulty recognising words that they already know, and most reading problems exist from the time the child began learning to read but were not observed by stakeholders. Reading difficulties can include issues with phonological processing, reading fluency or speed, and reading comprehension.

Oral language skills, particularly vocabulary skills, have a significant impact on the development of phonological awareness and reading skills [20, 21]. Language skills, word recognition, vocabulary, comprehension, experience, phonemes, cognitive ability, instructional strategies, and fluency have all been studied and they have shown a significant impact on reading skills [22]. Several studies have consistently demonstrated the significance of early reading development.

\section{Phonics instructional strategy and reading skills}

The importance of phonics reading instruction cannot be overstated because it helps pupils comprehend how words are represented in print. Children who are effectively taught phonemic awareness can manipulate the phonemes in letters [14] and will perform better when the instruction is "explicitly focused on one or two types of phoneme manipulations rather than multiple types" (p. 6). English, for example, is an alphabetic language, meaning that words in print are roughly represented at the phoneme level [23]. The goal of phonics is to simplify written language by breaking words into small and simple components. Phonics instruction is an evidence-based technique for teaching phonological awareness to learners who are typically developing as well as those who are reading-disabled [24].

A comprehensive meta-analysis conducted by the National Reading Panel [14], found that systematic phonics programmes were more effective than unsystematic phonics programmes or no phonics instruction at all in teaching typically developing children, at-risk children, and children with reading disabilities. In a systematic review of research on reading interventions for youths with moderate or severe intellectual disability, Roberts et al. [12] discovered 19 studies published between 1975 and 2011. The authors concluded that the interventions used did not address literacy instruction recommendations for students who are typically developing and did not consider all aspects of reading [11, 
12].

Phonemic awareness and letter-sound knowledge, on the other hand, have been shown to have a significant impact on students' reading abilities [25, 26, 27, 28]. Hill [29] examined eleven studies published between 2001 and 2013. Six of the studies were experimental or quasi-experimental in nature, and the remaining five were case studies. Most of the studies investigated used systematic phonics instructional techniques to teach pupils letter-sound correspondences and phonological awareness. Hill [29] concluded that the number of published studies on the impact of phonics instruction on improving the reading skills of pupils with disabilities had increased, and that these pupils appeared to benefit from it.

\section{Neurological impress strategy and reading skills}

The Neurological Impress Method (NIM) is a system for rapidly improving pupils' reading skills [30]. According to Flood et al. [31], the NIM was used as an intervention by researchers for teaching reading fluency during the 1960s and 1980s. This method is a suitable technique for teaching reading fluency to students with learning disabilities [31, 32]. Many studies have shown that NIM significantly improves reading fluency of pupils with learning disabilities [31, 32, 33, 34]. According to Lestari [35], the NIM is a supportive rather than a threatening method of improving reading. Furthermore, this method of instruction will help ensure that students feel confident while focusing on phonemic awareness and improved reading fluency [31]. The implication is that it is an enjoyable method for improving reading activities for children [35].

According to Schreiber [36, 37] and Schreiber and Read [38], students improved their understanding of the prosodic attributes of oral reading and verbal communication through regular practice. By doing this, they were able to integrate expressive and intonational characteristics of verbal communication into their reading, which aided in establishing phrase boundaries within and between sentences and conveying meaning. The one-on-one interaction between teacher and pupils affects the student's psychology [31]. Using the NIM to teach learners with learning disabilities could be particularly beneficial because it provides struggling readers with newfound confidence in their reading abilities, as well as a sense of accomplishment when reading fluently [39, 40] observed significant changes in students' attitudes and reading behaviour after using NIM to teach middle school students, as observed by parents, teachers, and herself. She claims that one of the reasons for the effectiveness of NIM is that it provides reading practice in a safe environment.

\section{Gender and Reading Skills}

Gender refers to a person's social characteristics that are typically associated with being either male or female.
Gender may have a broader impact on learning because the so-called 'gender gap' manifests itself in various aspects of learning, such as interest, attitude, needs, beliefs, and motivation. Although many studies have been conducted to investigate the relationship between gender and reading skills, the results have been inconsistent. Males outperformed females when the effect of gender on foreign language learning strategies was investigated [41]. According to Logan and Johnston [42], "girls consistently outperform boys in national literacy tests in British schools" (p. 202). According to Al-Shumaimeri [43], "schematic knowledge" (p. 11) is one of the factors that causes differences in reading comprehension between males and females, because the type of texts that cause the correct activation of schematic knowledge are better understood and comprehended by female reader.

Other research that examined the effect of gender on reading skills discovered that there were significant differences in reading comprehension between male and female students $[44,45]$. Females outperformed males in reading comprehension in general, according to the authors of these studies. Fahim et al. [46] and Sotoudehnama and Asadian [47], however, found no statistical differences in reading performance between male and female students. However, some findings revealed that females used significantly more metacognitive strategies than males [48, 49]. Young and Oxford [50] found no significant difference in strategy use between males and females in L1 (English) and L2 (Spanish) in reading texts. Males, on the other hand, reported monitoring their reading pace, reading strategies, and paraphrasing strategies more frequently than females.

\section{Purpose of the study}

The main purpose of the study was to determine the effectiveness of phonics and neurological impress instructional strategies on the reading skills of pupils with learning disabilities with a view of improving their teaching and learning outcomes.

\section{Research hypotheses}

The null hypotheses that were formulated and tested at 0.05 level of significance were:

1. There is no significant main effect of treatment (P-NIM) on reading skills of pupils with learning disabilities.

2. There is no significant main effect of gender on reading skills of pupils with learning disabilities.

\section{Methodology}

\section{Research Design}

The study adopted the pretest posttest control group quasi-experimental design with a $3 \times 2$ factorial matrix. It 
was used to determine effects of phonics and neurological impress instructional strategies on reading skills of pupils with learning disabilities. The design is represented as follows:

Experimental Group 1: (E1) $\mathrm{O}_{1} \mathrm{X}_{1} \mathrm{O}_{4}$ Experimental Group 3: (E1) $\mathrm{O}_{2} \mathrm{X}_{1} \mathrm{O}_{5}$ Control Group 2: $\quad$ (E2) $\mathrm{O}_{6} \quad \mathrm{O}_{6}$

\section{Sample and Sampling Techniques}

The population comprised all the pupils with learning disabilities in primary public or private schools in Ibadan Metropolis. Three schools were purposively selected based on their availability or participants that met criteria for selection from three local governments within the metropolis. Eighty-nine (89) pupils were screened by their classroom teachers through academic records, out of which forty-five pupils were diagnosed. The Pupil Rating Scale Revised for screening learning disabilities was used to ascertain the condition.

By screening, 45 students with learning disabilities who met the inclusion criteria for the study due to vocabulary difficulties were randomly assigned to treatment groups (two experimental groups and a control group). There were fifteen people in each experimental and control group. Because the participants possessed certain characteristics relevant to the purpose of the investigation, the samples were non-probability samples drawn from purposive sampling.

\section{Instrumentation}

Six research instruments were used: The Pupil Rating Scale (Revised), Umolu 100 high frequency words, Phonological Awareness Literacy Screening PreK (PALS-Prek), Picture Vocabulary Test, and Informal Reading Inventory. A pilot test was carried out to determine the dependability of the research instrument. The research instrument was given to twenty (20) students with learning disabilities who were not part of the study population. The Cronbach Alpha results were as follows: The pupils rating scale revised 0.75; VAK Learning Styles Inventory 0.82; Picture Vocabulary Test 0.75 ; PALS-Prek 0.82; Informal Reading Inventory 0.70 ; and Umolu's One Hundred High Frequency Words 0.85 .

\section{Procedures for Data Collection}

The study was divided into three stages namely: screening/pretest, intervention session, and posttest sessions. The Pupil Rating Scale was used for screening and identifying students with learning disabilities before administering the pretest to selected participants. Treatment sessions were conducted thrice a week for six weeks for the two experimental groups. Each treatment group received thirty-five (35) minutes per session. Pupils in the control group received a placebo treatment. A posttest was administered to each of the three groups at the end of six weeks.

\section{Method of Data Analysis}

To test null hypotheses of the study, the collected data were analysed using Analysis of Covariance (ANCOVA), while the estimated mean score was used to identify the source of significant main effects at the 0.05 level of significance.

\section{Results}

$\mathbf{H}_{0}$ 1: There is no significant main effect of treatment on reading skills

The results from Table 1 showed a significant main effect of treatments on reading skills of pupils with learning disabilities $\left(\mathrm{F}_{(2,42)}=43.178, p<.05, \eta^{2}=.762\right)$. This means there is significant difference in the mean treatment of pupils with learning disabilities on reading skills that were exposed to phonics and neurological impress instructional strategies when compared with the control group. Hence, hypothesis one is not accepted. It was therefore concluded that there is a significant main effect of treatments on enhancing the reading skills of persons with learning disabilities. This implies that phonics and neurological impress instructional strategies are effective in enhancing reading skills in persons with learning disabilities.

Table 1. ANCOVA showing the main and interaction effects of Treatment Group, Gender and Learning Style on reading skills

\begin{tabular}{|c|c|c|c|c|c|c|}
\hline Source & $\begin{array}{c}\text { Sum of } \\
\text { Squares }\end{array}$ & DF & Mean Square & F & Sig. & $\begin{array}{c}\text { Eta. } \\
\text { Sq }\end{array}$ \\
\hline Corrected Model & 8453.437 & 17 & 497.261 & 40.659 & .000 & .962 \\
Pre-test reading skills & 925.293 & 1 & 925.293 & 75.658 & .000 & .737 \\
Main Effect: & & & & & & \\
Treatment Group & 1056.114 & 2 & 528.057 & 43.178 & .000 & .762 \\
Gender & .413 & 1 & .413 & .034 & .856 & .001 \\
Error & 330.207 & 27 & 12.733 & & & \\
Total & 8783.664 & 44 & 12.230 & & & \\
\hline
\end{tabular}


Table 2. Estimated marginal means on treatment groups

\begin{tabular}{|c|c|c|}
\hline Treatment Groups & Mean & Std. Error \\
\hline Phonics & 80.729 & 1.089 \\
Neurological Impress & 73.242 & 1.276 \\
Control & 66.556 & 1.064 \\
\hline
\end{tabular}

Table 3. Estimated marginal means on gender

\begin{tabular}{|c|c|c|}
\hline Gender & Mean & Std. Error \\
\hline Male & 72.980 & .905 \\
Female & 74.137 & .917 \\
\hline
\end{tabular}

Table 2 showed that participants in the experimental groups obtained a higher mean score (80.7 and 73.2) while participants in the control group had a mean score of 66.5. This shows that participants in the experimental group had better reading skills than the participants in the control group. Hence, the treatment had a better effect on reading skills than the participants in the control group.

$\mathbf{H}_{\mathbf{0}}$ 2: There is no significant main effect of gender on reading skills.

The figures in Table 3 showed that gender had no significant effect on the enhancement of reading skills of pupils with learning disabilities $\left(\mathrm{F}_{(1,43)}=.034, p>.05, \eta^{2}\right.$ $=.001)$. This means that gender is not a predictor of reading skills enhancement of pupils with learning disabilities, particularly those that participated in phonics and neurological impress instructional strategies. This is so despite a very slim margin between the estimated mean score of female and male participants, which seems to favour female participants, as observed in Table 3. Hence, the null hypothesis, which states that there is no significant main effect of gender on reading skills enhancement of pupils with learning disabilities, is accepted.

\section{Discussion of Findings}

\section{Main effect of treatment on reading skills}

This study tested the hypothesis which stated there would be no significant main effect of treatment on reading skills of pupils with learning disabilities. The result showed that treatments (phonics and neurological impress) were significant in helping pupils with learning disabilities improve reading skills. The estimated marginal means analysis revealed that the participants exposed to phonics instructional methods had the highest mean score, followed by participants in the neurological impress group, while those in the control group had the lowest mean score. The findings in this study negates the findings of Bolkema [51] that the implementation of phonics instruction is not statistically significant, but the method may have supported readers with learning disabilities in developing their phonics skills when reading in isolation.
This current finding is consistent with Sitthitikul's [52] claim that phonics instruction had a significant effect on the reading skills of struggling readers in the early grades but had no effect on older children with reading problems.

The findings of the study support the assertions of Zaidat and Al-Awan [53] who reported that neurological impress is a useful tool for instructing reading fluency in learning disabilities. The findings also support Qian [54] and Grabe and Stoller [55], who assert that the more vocabulary a reader knows, the better the individual's reading skills. The findings also support the conclusions reached and confirm various studies [25, 31, 32, 33, 34] which found that effective decoding and read aloud strategies, such as phonics and neurological impress methods, assist students in rapidly expanding their vocabulary. The findings also corroborate the submission of the National Reading Panel [14] that reading aloud enhances language abilities and increases vocabulary. The findings of this study are not in agreement with the submission of Flood et al. [31, 56], which indicated that neurological impress methods had a positive and significant effect on two components of reading with the exclusion of oral vocabulary. The reason for the difference could be that learners read the same text almost simultaneously with their teacher serving as a positive reinforcement from the teacher. It may also help in building learners' self-confidence and in turn enjoying reading the text.

\section{Main effect of gender on reading skills}

The hypothesis stated that there is no significant main effect of gender on reading skills of pupils with learning disabilities. The results presented in Table 3 revealed that the effect of gender on reading performance skills was not significant. This means that gender has no significant impact on the reading skills of pupils with learning disabilities. This finding negates the results of the study carried out by Namaziandost et al. [57], which established significant difference in reading accuracy and fluency between male and female pupils. The result also negates the findings of Kaufman et al. [58] who reported that sexual orientation contrasts in reading were only noteworthy in youngsters and not in adult readers. The findings of this study were perhaps consistent with those 
of Vlachos and Papadimitriou [59], who noted that gender does not play does not play an important role in reading skills. In addition, studies such as those by Lan and Oxford [60], and Lu-Fang [61], reported that although gender initially plays a role in reading skills, ultimately there would be no significant discernible difference between both genders as adults.

\section{Conclusions}

This study concludes that phonics and neurological impress instructional methods had a significant effect on the reading skills of students with learning disabilities when compared to the control group. The phonics instructional method and neurological impression methods are learner centred which focused on enhancing active participation of learners in the classroom. However, phonics instructional method outperformed the other treatment in terms of improving participants' reading skills The findings of this study also revealed that the general assumption that females perform better than males and vice versa in reading is not applicable to pupils with learning disabilities. Based on the findings, it is recommended that teachers of pupils with learning disabilities should make use of phonics and neurological impress strategies when teaching reading skills because it can effectively improve their reading skills. Teachers who teach pupils with learning disabilities should be encouraged to attend seminars and conferences that could improve their knowledge and competence in teaching reading skills to pupils with learning disabilities. In addition, the study concludes that teachers should use appropriate instructional techniques to compensate for learning disabilities and actively encourage students to actively participate in reading instruction classes.

\section{Limitation}

Participants in this study comprised only forty-five students with learning disabilities purposively selected from three schools in Ibadan metropolitan, Nigeria. This limits application of conclusions to similar groups. The phonics and neurological impress instructions were held thrice a week since students were also expected to participate in other regular learning activities organised by their respective schools. However, every effort was made to ensure that each session was held as planned. Efforts were also made to keep the treatment session in quiet rooms, but due to space constraints, sessions were interrupted several times and had to be completed in another room. This was a source of continuous distraction for the pupils involved.

\section{Funding}

This work was supported by the South African
Research Chairs Initiative of the Department of Science and Innovation and National Research Foundation of South Africa. South African Research Chair: Education and Care in Childhood: Faculty of Education: University of Johannesburg South Africa [grant number: 87300, 2017].

\section{REFERENCES}

[1] Azan, A. "A Comparison of Three Selected Music/Reading Activities on Second-Grade Students' Story Comprehension, On-Task/Off-Task Behaviors, and Preferences for the Three Selected Activities." (Master's Thesis). Florida State University, College of Music, 2010.

[2] Hernandez, D. J. "Double Jeopardy: How Third-Grade Reading Skills and Poverty Influence High School Graduation." Annie E. Casey Foundation, 2011. https://files.eric.ed.gov/fulltext/ED518818.pdf

[3] Mee Beel, S., McCallum, R. S., \& Cox, E. A. "Toward a research-based assessment of dyslexia: Using cognitive measures to identify reading disabilities." Journal of Learning Disabilities, 36(6), 505-516, 2003.

[4] Shaywitz, S. E., \& Shaywitz, B. A. "The neurobiology of reading and dyslexia." The ASHA Leader, 12(12), 2001. http://www.ncsall.net/index.html@id=278.html

[5] Ihejirika, R. C. "Poor Attitude to Reading for Pleasure and Its Implications on Acquisition of Language Skills and Academic Achievements: The Case of Students of Secondary Schools in Nigeria." IOSR Journal of Humanities and Social Science (IOSR-JHSS) 19 (1), 43-46, 2014. https://doi.org/10.9790/0837-191104346

[6] Jacob, U. S, Ademokoya, J. A. Eni-Olorunda, J. T., \& Oyundoyin, B. M. "Pictorial Illustration for Enhancing Reading Skills of Learners with Intellectual Disability." Journal of Arts and Social Sciences Education, 6(1), 65-73.6(1), 2021. https://www.ijasseonline.com/wp-conten t/uploads/2021/06/Pictorial-Illustration-forEnhancing-Rea ding-Skills-of-Learners-with-Intellectual.pdf

[7] Anyaegbu, M. I., Aghauche, E. E., \& Nnamani, E. "Poor reading habit and the academic performance of junior secondary school students in Enugu South local government area of Enugu State." Education Research Journal, 6(8), 112-123, 2016. https://www.researchgate.ne t/publication/320621871_Poor_reading_habit_and the_aca demic performance of Junior_Secondary_School_student s_in_Enugu_South_Local_Government_Area_of_Enugu State

[8] Jacob, U. S. \& Pillay, J. "Effectiveness of music therapy on reading skills of pupils with intellectual disability." Cypriot Journal of Educational Science. 16(1), 251-265, 2021. https://doi.org/10.18844/cjes.v16i1.5526

[9] Drummond, K. "About reading disabilities, learning disabilities, and reading difficulties." Reading Rockets, n.d. https://www.readingrockets.org/article/about-reading-disab ilities-learning-disabilities-and-reading-difficulties

[10] Ahlgrim-Delzell, L., \& Rivera, C. "A content comparison of literacy lessons from 2004 and 2010 for students with 
moderate and severe intellectual disability." Exceptionality, 23(4), 258-269, 2015.https://doi.org/10.1080/09362835.20 15.1064417

[11] Browder, D. M., Wakeman, S. Y., Spooner, F., Ahlgrim-Delzell, L., \& Algozzinexya, B. "Research on reading instruction for individuals with significant cognitive disabilities." Exceptional Children, 72(4), 392-408, 2006.https://doi.org/10.1177/0014402906072004 01

[12] Roberts, C. A., Leko, M. M., Wilkerson K. L. "New directions in reading instruction for adolescents with significant cognitive disabilities." Remedial and Special Education, 34(5), 305-317, 2013. https://doi.org/10.1177/0 741932513485447

[13] Fletcher, J. M., Lyon, G. R., Fuchs, L. S., \& Barnes, M. A. "Learning disabilities. From identification to intervention." Guilford Press, 2007.

[14] National Reading Panel. "Teaching pupils to read: An evidence-based assessment of the scientific research literature on reading and its implication for reading instruction." National Institute of Child Health and Human Development, 2002.

[15] Salami, A. R. "Effect of language-experience and Fernald approaches in enhancing reading performance and attitude to reading of pupils with learning disabilities." (Unpublished Ph.D. thesis). University of Ibadan, 2016.

[16] Schuchardt, P. Hasselhorn, M \& Mähler, C. "Working memory deficits in children with specific learning disorders." Journal of Learning Disabilities, 41(6), 514-523, 2008. https://doi.org/10.1177/0022219408317856

[17] Bethel-Eke, O. A., \& Eremie, M. "Influence of learning disabilities on academic achievement of Junior Secondary School students in Imo state: Implications for counseling." International Journal of Innovative Social Science and Humanities Research 6(2), 52-61, 2018. https://www.researchgate.net/publication/343181193 Influ ence of Learning Disabilities on Academic Achieveme nt_of Junior_Secondary School_Students in_Imo_State Implications_for_Counseling

[18] Hulme, C., \& Snowling, M. J. "Reading disorders and dyslexia." Current Opinion in Pediatrics, 28(6), 731-735, 2016. https://doi.org/10.1097/MOP.0000000000000411

[19] Shaywitz, B. A., Shaywitz, S. E., Pugh, K. R., Mencl, W. E., Fulbright, R. K., Skudlarski, P., Constable, R. T., Marchione, K. E., Fletcher, J. M., Lyon, G. R., \& Gore, J. C. "Disruption of posterior brain systems for reading in children with developmental dyslexia." Biological Psychiatry, 52(2), 101-110, 2002.https://doi.org/10.1016/s 0006-3223(02)01365-3

[20] Dickinson, D. K., McCabe, A., Anastasopoulos, L., Peisner-Feinberg, E. S., \& Poe, M. D. "The comprehensive language approach to early literacy: The interrelationships among vocabulary, phonological sensitivity, and print knowledge among preschool-aged pupils." Journal of Educational Psychology, 95(3), 465 481, 2003. https://doi.org/10.1037/0022-0663.95.3.465

[21] Gathercole, S. E. "Nonword repetition and word learning: The nature of the relationship." Applied Psycholinguistics, 27(4), 513-543, 2006. https://doi.org/10.1017/S014271640

\section{3}

[22] Kame'enui, E. J., Good, R. H., III, \& Harn, B. A. "Beginning reading failure and the quantification of risk." In H. L. Heward, T. E. Heron, N. A. Neef, S. M. Peterson, D. M. Sainato, G. Cartledge, R. Gardner, L. D. Peterson, S. B. Hersch, \& J. C. Dardig. (Eds.), Focus on Behaviour Analysis in Education: Achievements, Challenges and Opportunities, Pearson Education, 2005, pp. 69-89.

[23] New South Wales Department of Education and Training. "The literacy teaching guide: Phonics." State of New South Wales, 2009.

[24] Castles, A., Rastle, K., \& Nation, K. "Ending the reading wars: Reading acquisition from novice to expert." Psychological Science in the Public Interest. 19(1), 5-51, 2018. https://doi.org/10.1177/1529100618772271

[25] Barker, R. M., Sevcik, R. A., Morris, R. D., \& Romski, M. "A model of phonological processing, language, and reading for students with mild intellectual disability." American Journal on Intellectual and Developmental Disabilities, 118(5), 365-380, 2013. https://doi.org/10.135 2/1944-7558-118.5.365

[26] Klusek, J., Hunt, A.W., Mirrett, P. L., Hatton, D. D. Hooper, S. R., Roberts, J. E., \& Bailey, D. B. "Reading and phonological skills in boys with Fragile X syndrome." Journal of Autism and Developmental Disorders, 45(6), 1699-1711, 2015. https://doi.org/10.1007/s10803-014-232 $8-\mathrm{y}$

[27] Dessemontet, R. S. \& de Chambrier, A-F. "The role of phonological awareness and letter-sound knowledge in the reading development of children with intellectual disabilities." Research in Developmental Disabilities, 4142; 1-12, 2015. https://doi.org/10.1016/j.ridd.2015.04.001

[28] Soltani, A., \&Roslan, S. "Contributions of phonological awareness, phonological short-term memory, and rapid automated naming, toward decoding ability in students with mild intellectual disability." Research in Developmental Disabilities, 34(3), 1090-1099. 2013. https://doi.org/10.10 16/j.ridd.2012.12.005

[29] Hill, D. R. "Phonics based reading interventions for students with intellectual disability: A systematic literature review." Journal of Education and Training Studies, 4(5), 205-214, 2016. https://doi.org/10.11114/jets.v4i5.1472

[30] Lerner, J., \& Johns, B. "Learning Disabilities and Related Mild Disabilities: Characteristics, Teaching Strategies, and New Directions" (11th ed.). Cengage, 2009.

[31] Flood, J., Lapp, D., \& Fisher, D. "Neurological impress method PLUS.” Reading Psychology, 26(2), 147-160, 2005. https://doi.org/10.1080/02702710590930500

[32] Barden, O. "From "acting reading" to reading for acting: A case study of the transformational power of reading." Journal of Adolescence and Adult Literacy, 53(4), 293-302, 2009. https://doi.org/10.1598/JAAL.53.4.3

[33] Feazell, V. "Reading acceleration program: A schoolwide intervention." The Reading Teacher, 58(1), 66-72, 2004. https://doi.org/10.1598/RT.58.1.6

[34] Wise, B. W., \& Snyder, L. "Clinical Judgments in Identifying and Teaching Students with Language based 
Reading Difficulties." USA: National Research Center on Learning Disabilities, 2007.

[35] Lestari, I. T. "Neurological Impress Method (NIM) Towards Student's Reading Ability." Channing: English Language Education and Literature, 3(2), 106-110, 2018. DOI: https://doi.org/10.30599/channing.v3i2.470

[36] Schreiber, P. A. "On the acquisition of reading fluency." Journal of Literacy Research. 12(3), 17-186, 1980. https://doi.org/10.1080/10862968009547369

[37] Schreiber, P. A. "Understanding prosody's role in reading acquisition." Theory Into Practice, 30(3), 158-164, 1991. https://doi.org/10.1080/00405849109543496

[38] Schreiber, P. A., Read, C. "Children's use of phonetic cues in spelling, parsing, and - maybe - reading." Bulletin of the Orton Society. 1980, 30, 209-224, 1980 https://doi.org/10.1007/BF02653719

[39] Elia, E. "The implementation of neurological impress method in teaching reading hortatory exposition at Grade Eleventh students of Ma Lab UIN-SU Medan." (A S1 Degree thesis) State Islamic University of North Sumatera Medan, 2018. http://repository.uinsu.ac.id/4365/1/SKRIPSI $\% 20$ ERNIM\%20ELIA.pdf

[40] Bedsworth, B. "Thinking and learning across the curriculum: The Neurological Impress Method with Middle School Poor Readers. Journal of Reading, 34(7), 1991. DOI: $10.2307 / 40014585$

[41] Tercanlioglu, L. "Exploring gender effect on adult foreign language learning strategies." Issues in Educational Research, 14(2), 181-193, 2004.http://www.iier.org.au/iier 14/tercanlioglu.html

[42] Logan, S., \& Johnston, R. "Gender differences in reading ability and attitudes: Examining where these differences lie.' Journal of Research in Reading, 32(2), 199-214, 2009. https://doi.org/10.1111/j.1467-9817.2008.01389.x

[43] Al-Shumaimeri YAN. "Gender Differences in Reading Comprehension Performance in Relation to Content Familiarity of Gender-neutral Texts." Paper presented at the Second International Conference: Language, Culture and Literature, Minia University, Egypt, 2005.

[44] Brantmeier, C. "Gender, violence-oriented passage content and second language reading comprehension. The Reading Matrix, 4(2), 1-19, 2004. https://readingmatrix.com/article s/brantmeier/article3.pdf

[45] Chiu, M. M., \& McBride-Chang, C. "Gender, context, and reading: A comparison of students in 43 countries." Scientific Studies of Reading, 10(4), 331-362, 2006. https://doi.org/10.1207/s1532799xssr1004_1

[46] Fahim, M., Barjesteh, H., \& Vaseghi, R. "Effects of critical thinking strategy training on male/female EFL learners' reading comprehension." English Language Teaching, 5(1), 140-146, 2012. https://doi.org/10.5539/elt.v5n1p140

[47] Sotoudehnama, E., \& Asadian, M. "The effect of gender-oriented content familiarity and test type on reading comprehension." Journal of Teaching Language Skills, 30(2), 155-178, 2011.

[48] Kaylani, C. (1996). "The influences of gender and motivation on EFL learning strategy use in Jordan." In R.
Oxford (ed.), Language learning strategies around the world: Cross- cultural perspectives, University of Hawaii, Second Language Teaching and Curriculum Center, 1996, pp. $75-88$.

[49] Sheorey, R. "An examination of language learning strategy use in the setting of an indigenized variety of English." System, 27(2), 173-190, 1999. https://doi.org/10.1016/S03 46-251X(99)00015-9

[50] Young, D. J., \& Oxford, R. "A gender-related analysis of strategies used to process input in the native language and a foreign language." Applied Language Learning, 8, 43-73, 1997.

[51] Bolkema, S. "Influence of phonics instruction on reading fluency and accuracy." (Unpublished Master's thesis) Northwestern College, 2019.

[52] Sitthitikul, P. "Theoretical review of phonics instruction for struggling/beginning readers of English.” PASAA: Journal of Language Teaching and Learning in Thailand, 48, 113-126, 2014.

[53] Zaidat, A. H., \& Al-Awan, M.S.A. "The effectiveness of neurological impress method on reading fluency students with learning disabilities in Amman, Jordan." International Education Studies, 11(1) (165-171), 2018. https://doi.org/1 $0.5539 /$ ies.v $11 \mathrm{n} 1 \mathrm{p} 165$

[54] Qian, D. D. "Investigating the relationship between vocabulary knowledge and academic reading performance." Language Learning, 52(3), 513-536, 2002. https://doi.org/ $10.1111 / 1467-9922.00193$

[55] Grabe, W., \& Stoller, F. L. "Teaching and Researching Reading." Longman, 2002.

[56] Flood, J., Lapp, D., Squire, J. R., \& Jensen, J. M. "Handbook of research on teaching the English language arts" (2nd ed.). Lawrence Erlbaum Associates, 2003.

[57] Namaziandost, E., Imani, A., Banari, A., \& Shakibaei, G. "An investigation of gender differences in L2 reading accuracy and fluency among Iranian Intermediate EFL learners." Journal of New Advances in English Language Teaching and Applied Linguistics, 2(1) 259-280, 2020. https://www.google.com/url?sa=t\&rct=j\&q=\&esrc=s\&sour ce $=$ web\&cd $=\&$ ved $=2$ ahUKEwiRrIby9O yAhXIRUEAHf GoACEQFnoECAQQAQ\&url=http $\% 3 \overline{\mathrm{A}} \% 2 \mathrm{~F} \% 2 \mathrm{Fwww}$.jel tal.ir\%2Farticle 101153 f472358020730750c02720ff547b a27c.pdf\&usg $=\bar{A}$ OvVaw01y97Pr2riSYHbMhRwnrGl

[58] Kaufman, A. S., Kaufman, J. C., Liu, X., \& Johnson, C. K "How do educational attainment and gender relate to fluid intelligence, crystallized intelligence, and academic skills at ages 22-90 years?" Archives of Clinical Neuropsychology, 24(2), 153-163, 2009. https://doi.org/10.1093/arclin/acp015

[59] Vlachos, F. \& Papadimitriou, A. "Effect of age and gender on children's reading performance: The possible neural underpinnings." Cogent Psychology, 2(1), 2015. https://doi.org/10.1080/23311908.2015.1045224

[60] Lan, R., \& Oxford, R. L. "Language learning strategy profiles of elementary school students in Taiwan." International Review of Applied Linguistics in Language Teaching 41(4), 339-379, 2003.https://doi.org/10.1515/iral .2003 .016 
[61] Lu-Fang, L. "Senior high school students' reading comprehension of graded readers." Journal of Language
Teaching and Research, 1 (1) 20-28, 2010. https://doi.org/10.4304/jltr.1.1.20-28 